\title{
RURAL REGIONS WITH DIFFERENT LANDSCAPE FUNCTIONS: COMPARISON ANALYSIS OF TWO PILOT REGIONS IN HUNGARY
}

\author{
FILEPNÉ KOVÁCS, K. ${ }^{* 1}$ - VALÁNSZKI, I. ${ }^{1}-$ JOMBACH, S. ${ }^{1}$ - CSEMEZ, A. ${ }^{1}-$ \\ SALLAY, Á. ${ }^{1}$ \\ ${ }^{1}$ Corvinus University of Budapest, Department of Landscape Planning and Regional \\ Development \\ H-1118 Budapest, Villányi út 29-43. \\ (phone: +36-1-482-6281; fax: +36-1-482-6338) \\ *Corresponding author \\ e-mail:krisztina.kovacs@uni-corvinus.hu \\ (Received 22 $2^{\text {nd }}$ July 2014; accepted $8^{\text {th }}$ Aug 2014)
}

\begin{abstract}
Nowadays a popular research field is the use of indicators, especially landscape indicators for the analysis of landscape functions. We have elaborated 13 complex indicators in 6 groups to compare the level of different landscape services and explore the relation between landscape use and economic situation in two rural regions of Hungary. We have chosen rural regions with different natural and economic conditions. The level of regulation and supporting functions are reflected by the group of indicators of environment and biodiversity. Habitat function was analyzed by the rate of protected areas. For the assessment of the visual and cultural value we analyzed the naturalness and diversity of the landscape and cultural heritage. The provisioning services cover mostly the cultivation of the landscape; we assessed intensity of agriculture, forestry and tourism. As an additional analysis we assessed the availability and economic conditions of the pilot regions. The results have shown interesting correlation between the level of landscape functions, availability and economic situation of the analyzed regions. Based on our researches we found that in course of landscape function analysis as a base of rural development it is important to analyze not just the relevant functions but the connections between them, since they may act differently on each other in different situations. While in case of regulation, supporting and habitat function values of Gönc micro-region exceeds Csorna, the values of availability and economic situation Csorna has higher values.
\end{abstract}

Keywords: Landscape function; Ecosystem services; Landscape management; Sustainable rural development; Micro-region of Csorna, Gönc

\section{Introduction}

Always more attention is paid on rural development and landscape management. In our study we apply landscape function analysis using complex landscape indices to indentify the most appropriate landscape management guidelines and rural development policies. The terms of ecosystem services and landscape functions became frequently used terminologies within the scientific community. The most important difference in the approach of the terms is rooted in the field of ecology and was originally designed for the assessment of (semi-)natural ecosystems (Costanza et al. 1997). Meanwhile the approach to landscape functions came principally from landscape ecology and planning (Bastian et al., 2006; De Groot and Hein 2007).

Ehrilch and Ehrilch (1981) were the first to mentioned ecosystem services and COSTANZA et al. in 1997 assessed the economic value of ecosystems. Up till now the most detailed, extensive scientific study was elaborated by the Millennium Ecosystem Assessment program initiated by the UN in 2001 (MEA 2005). In the frames of the

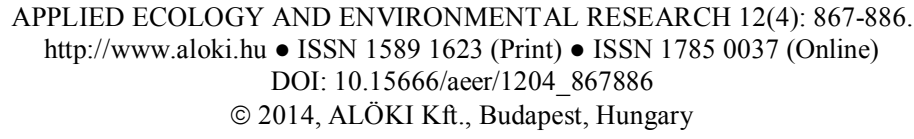


program researchers analyzed the relation of social wellbeing and ecosystem services. There is a vast literature about the theory and application of ecosystem services. There are a number of options to group assets offered by nature, very often the next being an advanced version of the previous one, thus so much similar to one other (de Groot, 1992, 2006; Costanza et al., 1997; MEA, 2005). In case of four groups of services there is a consensus of opinion: provisioning services (food, timber, etc.), regulating services (climate control, water purification, etc.), supporting (soli formation, nutrient cycling) and information services (recreation, education, etc.). These services can be described in terms of carrying capacity and spatial needs (minimum critical ecosystem size) of the natural ecosystems which provide them. Provisioning functions mean many resources of the nature for human use (food, raw material-fiber, timber, etc.). Information functions cover all the services related to recreation, reflection, cognitive development and aesthetic experience. Finally de Groot distinguishes carrier functions which include cultivation, habitation and transportation. This group of services includes all the human activities which converse the original ecosystem. Naturally there are overlaps and interactions between the different functions, for example the carrier function also offer other goods such as cultivated landscape maintain regulation services and have aesthetic qualities, etc. (de Groot, 2006).

The term of landscape functions has been developed parallel with the term of ecosystem services in other scientific field. This concept as an integrative framework establishes the connection between natural, economic, social sciences and policy sectors. So landscape services are more often defined as 'the capacity of the landscape to provide goods and services that satisfy human needs, directly or indirectly' (Willemen et al., 2010). Bastian (1997) grouped landscape functions according to the three pillars of sustainability, as, production (economic), anthropocentric (society) and regulatory (ecological) functions.

In the model of landscape functions Brandt and Vejre (2004) distinguished land use functions referring to material processes connected with land use. Lamarque et al. (2011) highlights the fact that a clear demarcation between landscape functions and land use functions is not possible. According to Lamarque there are four types of services, which mostly overlap with each other: ecologic services, ecosystem services, landscape functions, land use functions. Demarcation is possible along the following dimensions: service provider (species/population, ecosystems/habitats, land use/land cover) goal (biodiversity protection, multifunctional landscape), scale (global, regional, local).

The foregoing shows that the two concepts are formed from different scientific fields, using different terminology, but carrying the same meaning (Schlößer et al., 2010). For the non ecologic scientific fields is more attractive to use the term of "landscape" than "ecosystem", furthermore term of landscape function is harmonizing with the habitat of people, the living environment (Hermann et al. 2014).

The landscape functions are provided by the biological and landscape diversity so it is inevitable to maintain the biodiversity and to turn back the unfavorable processes. It is particularly true for the rural landscapes which are the most important food production places of the humankind, which next to the production function fulfils important social/cultural and landscape/nature protection functions as well (EEC, 1992).

In European context landscape management means: "...action, from a perspective of sustainable development, to ensure the regular upkeep of a landscape, so as to guide and harmonize changes which are brought about by social, economic and environmental process" (Council of Europe 2000, Chapter I, Article 1, e). In spite of the 
comprehensive, international interpretation of the concept, landscape management has different meaning for researchers, decision makers, planners (Gobster, 1999).

In Hungary especially among researchers in the field of agricultural sciences is landscape management popular mostly with the expression of environment and landscape management. According to Belényesi (2008) the most important feature of the concept is to strive for activities, management forms fitting local conditions meanwhile taking into consideration the economic, social, environmental and regional functions of the landscape. Ángyán (2004) emphasized environmental and landscape management is equivalent with "multifunctional" agriculture, where next to the traditional production function environmental, social, employment and cultural tasks also come up. For landscape architects and planners according to the interpretation of Csemez (1996) it means harmonizing the objectives of landscape reclamation nature, landscape and environmental protection and sustainable regional development and fitting them into the system of landscape elements. In our interpretation in the frames of landscape management such system of different land use forms should be maintained which helps the harmonious functioning of the landscape, ensures on the long run the sustainable functioning of landscape functions furthermore strives to meet the current needs of society Filepné Kovács (2013).

In rural regions for sustainable landscape management and rural development is extremely important to analyze the level of landscape functions as in rural regions people still live from the goods of the landscape (agriculture, tourism), or people have chosen rural settlements for living because of the quality of the environment.

As pilot areas we have chosen two rural regions. According to the classification of the OECD and EU, both of them belong to predominantly rural areas (more than $50 \%$ of the area's population lives in (rural) communities, where the density of population is under 120 persons $/ \mathrm{km}^{2}$ ) (OECD, 2007).

Based on the typology used in the European Union 96\% of the territory of Hungary is classified as rural areas accommodating $74,5 \%$ of the population. The ratio of predominantly rural areas is $58,3 \%$, with a proportion of $31,3 \%$ in the total population, which is 3,2 times higher than the EU average (9,7\%).

Rural areas mostly offer healthy living environment suitable for rest and recreation, generally have rich, although rundown landscape, architectural and cultural heritage. Public utilities, infrastructure and services are usually worse than in urban areas and the transportation and access systems are extremely bad. The general income rate is lower, rate of unemployment is higher, population is aging, high rate of migration etc. Both pilot areas have negative demographic tendencies.

We consider landscape function analysis highly important for the sustainable development of rural regions which make up the majority of Hungary and also of Europe. For our research we formed the following objectives:

- To compare the environmental and economic situation of pilot areas (regional analysis)

- To detect determinant landscape indices to reflect the level of landscape functions

- To compare the landscape functions within the pilot areas

- To explore the relation between the level of landscape functions and use of the landscape and the economic conditions of rural areas

- To highlight the importance of landscape management in case of rural development 


\section{Methods and materials}

Following the concept of landscape functions, we elaborated complex landscape indicators to compare the level of different landscape services and explore the relation between landscape use and economic situation of the analyzed regions. For the assessment of landscape functions we used wide range of complex indicators (13 different indicators in 6 groups). The used landscape indicators mostly cover all types of landscape services from the most important classification systems (Table 1). We used the data of the Hungarian Statistic Office, and other types of databases (Spatial planning and development Information System - TEIR, database of national monuments, database of landscape values - TÉKA, nature and environmental protection databases TIR) for the evaluation of the level of the landscape services and characterization of settlements and sub-regions.

The level of regulation and supporting functions are reflected by the group of indicators of environment and biodiversity. For the assessment of environmental integrity we adopted the method elaborated by Koschke (2012) and his fellow researchers in. This method reflects a multi-criteria approach, based on the land cover data (Corine Land Cover data base), experts assessed all landscape functions of different land use forms. The result is a schematic, map based analysis, enabling the relative simple and easy assessment of greater territorial units as well.

Biodiversity in cultivated landscape is mostly defined by the diversity of different land use forms which is reflected by the Shannon diversity index. The diversity of the land use system is measured by the Shannon diversity index which measures the type and size of different land use forms. The value of a diversity index increases when the number of the land use types increases and when evenness increases.

Due to the decades-long traditions of nature protection there are wide scale of data available so we assessed the ratio of nature protection areas of national importance, proportion of Natura 2000 areas, Ramsar sites and Biosphere reserves furthermore the proportion of National Ecologic Network (special tool of landscape protection in the spatial plans with building restrictions mostly NET areas include all other protected areas and other areas of ecologic value). The same factors appear in different indicators (Natura 2000 for example), but this does not modify the relation between them, neither the results since the whole system is relative.

In most classifications there are landscape services distinguished related to the nonmaterial goods offered by the landscape (Anthropocentric services, Culture and amenity etc.). The assessment of the visual value of the landscape is a very difficult question. Several methods, indicators were elaborated for the assessment of visual diversity applied on different spatial level. A few indicators for visual assessment: openness and closeness (OECD, 1997), visibility (USDA, 1995), tranquility (Swanwick, 2002), land use patterns (OECD, 2001), complexity (Kaplan et al., 1989), variety (Daniel, 2001). From our point of view the quality of the landscape scenery highly depends on naturalness (Clay and Smidt, 2004) and diversity (EEA, 1998).

In our analysis the indicator of naturalness is calculated on the base of proportion of extensive land use forms. The classes of CORINE Land Cover were classified by scale of extensive use. At the end of the selection we labeled 20 land cover forms as extensive (different forest types, wetlands, bushes). Visual diversity measured by the number of distinct land use forms per unit area (Kollányi, 2004). There are several methods for determination of the index, from which (due to the spatial scale and availability of data) we have chosen the distribution of valuable edge types per unit area. From the point of 
landscape aesthetics forests and water edges represent the highest values. For the assessment of landscape diversity we calculated the forest (three times the weight) and water edges divided by the area of settlements. The last of the indicator group is intended to measure cultural significance. Cultural heritage indicator includes the number of monuments of the settlements.

The provisioning services cover mostly the cultivation of the landscape. In spite of the overall reduction of the weight of agriculture and forestry in GDP and employment, agricultural use is still important in rural especially backward regions from the point of economy and forming the landscape. The group of indicator of agriculture and forestry includes arable land potential (proportion of arable land indicating the fertility (AK index of land quality) as well), forestry potential (proportion of forests). The intensive fruit, vegetable gardens, vine yards increase the income-generating capacity of agriculture which is represented by the vine and fruit potential indicator (proportion of vine yards and other intensive horticulture using Corine Land Cover database).

Tourism shows another aspect of attractiveness and use of the landscape. We assessed the accommodation capacity and number of guest nights in the settlements (tourism flow indicator). Generally availability in rural development is a cardinal question. We highlighted the differences in availability between the pilot-regions and sub-regions by calculating the time of availability of motorway junction (minutes), county seat, seat of micro-region and counting railway stations which improves availability.

As we consider landscape function analysis as a tool of rural development and in order to present the differences in the economic circumstances as an additional analysis we elaborated a complex economic indicator using data of the Hungarian Statistic Office. The economic indicator highlights the income generating capacity of the settlements represented by total domestic income per taxpayers and ratio of taxpayers in the settlement.

First we aggregated the spatial data on settlement level. The values of our indicators varied between rather different scales, so we harmonized them into a common dimension. The values $(32+34)$ of all settlements of both pilot regions were ranged one after the other. Then the values were divided on a scale from 1 to 10 . So we can asses not just the situation of settlements in the pilot area but the range or relation of the settlements of both pilot regions general as well. Thanks to the employed method we could aggregate the indicators into 6 groups.

\section{Introduction of the pilot regions (Hanság-Rábaköz and Micro-region of Gönc)}

We have chosen two rural regions lying along the Western and North-Eastern boarders of Hungary (Figure 1). Both pilot regions contain backward settlements and suffer severe depopulation processes and are peripheries or have peripheral parts.

Micro-region of Csorna situated in the Small-Plain between the great centers of the County Györ-Moson-Sopron. The micro-region of Csorna holds most of the settlements of Hanság and Rábaköz together. For centuries especially in Rábaköz agriculture was the most important economic basis of the region. From the point of view of tourism important landscape conditions, the area is in a shadow-situation, the Rábaköz does not have outstanding attractions but it is situated between the Szigetköz/Danube and Lake Fertö recreational areas of national importance, in the vicinity of the Austrian border. The micro-region can be characterized by rural small settlement structure. The wetlands, swamps, and forests of Hanság and the banks and gallery forests of river Rába 
are of great ecological value. In the micro-region two characteristic groups of settlements can be drawn because of the different landscape conditions: 1. Hanság and Tóköz 2. Rábaköz and Rábamente.

The micro-region of Gönc is located in the North-Hungarian Region, in BorsodAbaúj-Zemplén county. The region, thus the settlements belong to the most disadvantaged areas of the country. The sample area can be divided into two main parts with different landscape characteristics. The largest portion of the micro-region is located in the upper valley of the Hernád river, while about two thirds of that is on the northwestern side of the mountains of Zemplén. The subject area consists of two small towns (Gönc and Abaújszántó) and 30 villages grouped around the towns. The SlovakHungarian border, which runs along the northern perimeter of the research area, has got a direct influence on the settlements of the micro-region. It is important to note that the wider region's largest center, Kosice is half as far from Gönc as Miskolc, the county seat. Especially after the Schengen's border opening the proximity of the second largest city in Slovakia, Kosice with a population of 300,000 was appreciated.

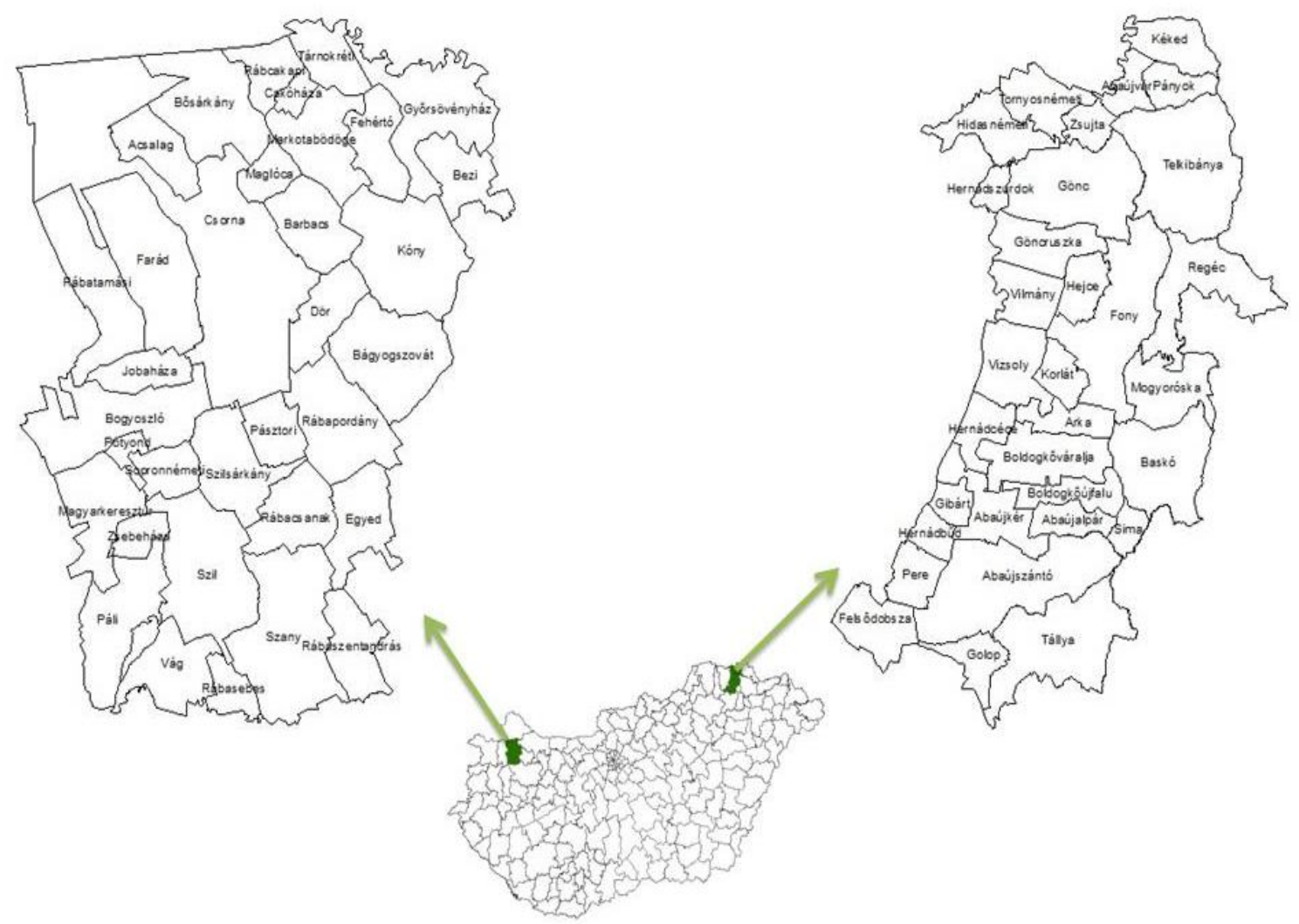

Figure 1. Location of the pilot-regions, micro-region of Csorna, and Gönc

The structure of the micro-region (settlement network and infrastructure network) is determined by the landscape and geographical (topography, hydrography) conditions.

Both pilot-regions lie near the borders of Hungary and are mostly characterized by high settlement density with mostly small villages. If we consider natural and economic conditions, we have chosen two characteristically different micro-regions: Gönc lies in one of the most backward region and Csorna and its surrounding in the second richest region of Hungary. 
Table 1. Relation between ecosystem services, landscape function concepts and the used landscape indicators of the research

\begin{tabular}{|c|c|c|c|c|c|c|c|c|c|c|c|c|c|c|c|}
\hline 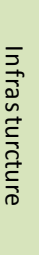 & 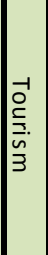 & & 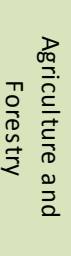 & & & 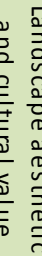 & & & $\begin{array}{l}2 \\
0 \\
0 \\
\frac{1}{0} \\
0 \\
0 \\
0 \\
0 \\
0 \\
0 \\
\stackrel{0}{0} \\
\frac{0}{1}\end{array}$ & & 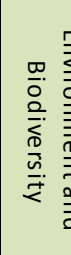 & & 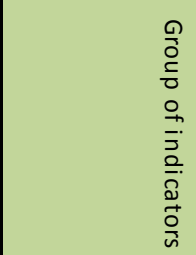 & & 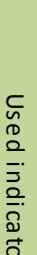 \\
\hline 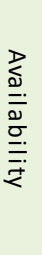 & 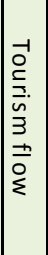 & 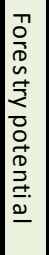 & 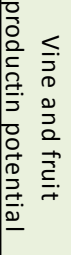 & 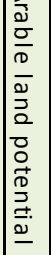 & 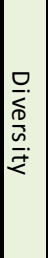 & 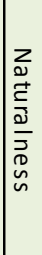 & 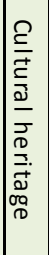 & 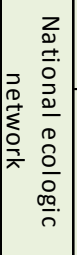 & 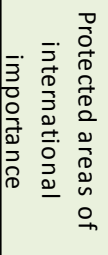 & 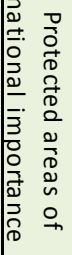 & 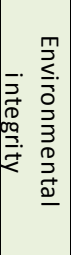 & 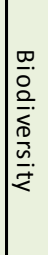 & 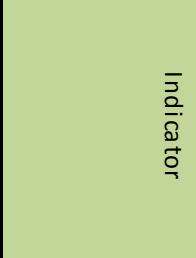 & & 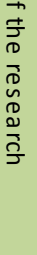 \\
\hline & & & & & & & & $\times$ & $\times$ & $\times$ & $x$ & $x$ & Regulation & \multirow{3}{*}{ 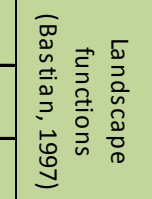 } & \\
\hline$\times$ & & $x$ & $x$ & $x$ & & & & & & & & & Production & & \\
\hline & $x$ & & & & $x$ & $x$ & $\times$ & & & & & & Anthropocentric & & \\
\hline & & & & & & & & & & & $x$ & $x$ & Ecosystem & \multirow[t]{3}{*}{ 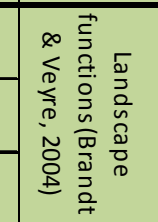 } & \\
\hline$\times$ & & $x$ & $x$ & $\times$ & & & & $x$ & $x$ & $x$ & & & Land use & & 드. \\
\hline & $x$ & & & & $x$ & $x$ & $x$ & & & & & & Transcending & & 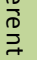 \\
\hline & & & & & & & & & & & & & Regulation & & 票 \\
\hline & & & & & & & & & & & $x$ & $x$ & Habitat & & $\stackrel{\Omega}{ \pm}$ \\
\hline$\times$ & & $x$ & $x$ & $x$ & & & & $x$ & $\times$ & $x$ & & & Provision & & $\sum_{n}^{n}$ \\
\hline & $x$ & & & & $x$ & $x$ & $x$ & & & & & & $\begin{array}{l}\text { Culture and } \\
\text { amenity }\end{array}$ & & 焉 \\
\hline$x$ & & & & & $x$ & $x$ & $x$ & $x$ & $\times$ & $x$ & & & $\begin{array}{c}\text { Complete } \\
\text { delineation }\end{array}$ & \multirow{3}{*}{ 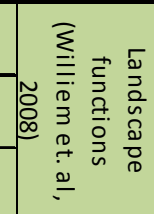 } & $\begin{array}{l}\bar{D} \\
\frac{2}{a}\end{array}$ \\
\hline & $x$ & $x$ & $\times$ & $x$ & & & & & & & $x$ & $x$ & $\begin{array}{c}\text { Partial } \\
\text { delineation }\end{array}$ & & 䓠 \\
\hline & & & & & & & & & & & & & No delineation & & $\overbrace{亏}^{\circ}$ \\
\hline & & & & & & & & & & & & & Supporting & \multirow{4}{*}{ 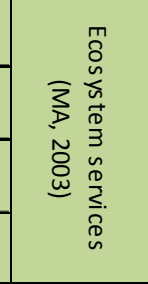 } & जे \\
\hline & & & & & & & & $x$ & $\times$ & $\times$ & $\times$ & $x$ & Regulation & & $\stackrel{D}{n}$ \\
\hline$x$ & & $x$ & $x$ & $x$ & & & & & & & & & Provision & & 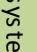 \\
\hline & $x$ & & & & $x$ & $x$ & $x$ & & & & & & $\begin{array}{c}\text { Culture and } \\
\text { amenity }\end{array}$ & & 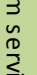 \\
\hline & & & & & & & $x$ & & & & & & $\begin{array}{c}\text { Global non- } \\
\text { proximal }\end{array}$ & \multirow{5}{*}{ 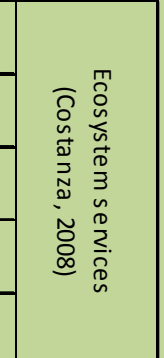 } & న్ \\
\hline & & & & & & & & & & & $x$ & $x$ & Local proximal & & \\
\hline$\times$ & & & & & & & & & & & & & $\begin{array}{c}\text { Directional flow } \\
\text { related }\end{array}$ & & \\
\hline & $x$ & $\times$ & $x$ & $x$ & & & & & & & & & In situ & & \\
\hline & & & & & $x$ & $x$ & & $\times$ & $x$ & $\times$ & & & $\begin{array}{l}\text { User movement } \\
\text { related }\end{array}$ & & \\
\hline
\end{tabular}


However southern Rábaköz can be characterized as an inner-periphery with decreasing population. The pilot regions consist of different landscape character types. Gönc and its surrounding is a mountainous varied landscape with the valley of Hernád river. Hanság and Rábaköz is a plain landscape and while Hanság with the remnants of the former vast marshland is rich in ecologic values, Rábaköz is mostly an intensive cultivated cultural landscape.

\section{Results}

First the chosen and employed indicators were pre-tested in both sample areas. To detect the relevance of each indicator we analyzed the differences between the highest and the lowest value and the variety of the values. Table 2 shows, that the same indicator could not always detect the same differences or relationships in different pilot regions. We also found that some of the indicators indicate better the differences between the settlements, while others are more suitable for analysis entire microregions. Despite of the formers we decided to employ all of our indicators for the following steps, while as Table 2 presents all of them have got some relevance for the evaluation.

\section{Detailed comparison of landscape indices in the pilot regions}

The research results allow detailed comparison of landscape functions between the pilot regions and a sub-regional analysis as well (Figure 2). First we present our results according to the landscape indicator groups and afterwards summarize them.

Table 2. Relevance of the indices in the pilot areas

\begin{tabular}{|c|c|c|c|}
\hline \multicolumn{2}{|c|}{ Used indicators of the research } & \multicolumn{2}{|c|}{ Relevance of the sample areas } \\
\hline $\begin{array}{l}\text { Group of } \\
\text { indicators }\end{array}$ & Indicator & Micro-region of Gönc & $\begin{array}{l}\text { Micro-region of Hanság- } \\
\text { Rábaköz }\end{array}$ \\
\hline \multirow{2}{*}{$\begin{array}{l}\text { Environment } \\
\text { and } \\
\text { Biodiversity }\end{array}$} & Biodiversity & $* *$ & $* *$ \\
\hline & Environmental integrity & $* *$ & $* *$ \\
\hline \multirow{3}{*}{$\begin{array}{l}\text { Nature } \\
\text { protection }\end{array}$} & $\begin{array}{l}\text { Protected areas of national } \\
\text { importance }\end{array}$ & $* *$ & $*$ \\
\hline & $\begin{array}{c}\text { Protected areas of } \\
\text { international importance }\end{array}$ & $* * *$ & $* * *$ \\
\hline & National ecologic network & $* * *$ & $* * *$ \\
\hline \multirow{3}{*}{$\begin{array}{l}\text { Landscape } \\
\text { aesthetic and } \\
\text { cultural value }\end{array}$} & Cultural heritage & $* * *$ & $* * *$ \\
\hline & Naturalness & $* * *$ & $* * *$ \\
\hline & Diversity & $* * *$ & $* * *$ \\
\hline \multirow{3}{*}{$\begin{array}{l}\text { Agriculture and } \\
\text { Forestry }\end{array}$} & Arable land potential & $* * *$ & $* * *$ \\
\hline & $\begin{array}{c}\text { Vine and fruit productin } \\
\text { potential }\end{array}$ & $* * *$ & $* * *$ \\
\hline & Forestry potential & $* * *$ & $* * *$ \\
\hline Tourism & Tourism flow & $* * *$ & $* *$ \\
\hline Infrasturucture & Availability & $* * *$ & $* * *$ \\
\hline
\end{tabular}

*** Relevant: difference between the highest and lowest values is triple, different values occur in at least $50 \%$ of the settlements

** Less relevant: difference between the highest and lowest values is one and half times, different values occur in at least $25 \%$ of the settlements

* Not relevant: difference between the highest and lowest values is less than half times, different values occur in less than $25 \%$ of the settlements 


\section{Environment and Biodiversity}

The biodiversity indicator shows characteristic differences in both pilot regions. Settlements of Hanság and Tóköz dispose of high natural variety, high rate of semi natural, natural vegetation and protected areas (highest value Tárnokréti 56,4), low or medium intensity of cultivation, diverse land use, small patches of meadows, forest belts and plough fields. Meanwhile Rábaköz is characterized by high intensity of agricultural production which leads to a monotonous landscape with low ecologic value. This reflects in low values of biodiversity (lowest value 23). In Rábaköz the only exceptions are the settlements along river Rába where a narrow belt of gallery forests, meadows give high biodiversity (Rábasebes).

The indicator of environmental integrity reflects similar results, so similar differences between the sub-regions as the indicator of biodiversity. The highest values belong to settlements of Hanság, Tóköz, Tárnokréti, Csorna (51), Fehértó (49), Barbacs (47), Maglóca (46). Exceptions are Bogyoszló and Páli from Rábaköz. All settlements with low values are settlements from Rábaköz.

The analysis of diversity draws also in Gönc micro-region an interesting pattern of the settlements. The most diverse area is the northwestern part of the region and also some of the southern settlements, while the eastern half of the sample area seems to be the least diverse. This picture is rather contradictory with the natural protected areas, which are mainly located the least diverse part of the micro-regions. The reason of this is the fact, that the majority of the protected areas covered by forest and the pattern of the land uses do not show less variability (e.g. Baskó $(23,76)$, Regéc $(25,62))$. In contrast, along the river Hernád plenty of small lakes (which were mainly former gravel pits), backwaters are located. In addition narrow belts of gallery forests also increase the diversity of these settlements. The highest values detected in Hernádszurdok $(57,15)$, Zsujta $(52,12)$ and Hidasnémeti $(49,67)$.

In the case of environmental integrity in Gönc micro-region the borderline between the Mountains of Zemplén and the Valley of Hernád is outlined clearly. The highest values were calculated in the settlements, which are covered mainly with forest: Regéc $(93,27)$, Mogyoróska $(89,65)$, Telkibánya $(89,16)$, Baskó $(88,87)$ and Fony $(84,96)$. The lowest values belong to the settlements, which have large arable areas: Felsödobsza $(37,92)$, Vilmány $(38,44)$, Vizsoly $(39,26)$ and Göncruszka $(40,14)$.

\section{Nature protection}

In micro-region of Csorna the share of protected areas in the region of Hanság and Tóköz is really high, here we can find areas of the National Park Fertö-Hanság (Fehértó, Barbacs, Csorna, Maglóca, Kóny, Dör, Bősárkány, Győrsövényház, Markotabödöge, Acsalag) and also the protected areas of international importance (Natura 2000 areas, Ramsar site) are here. Up till the $18^{\text {th }}$ century Hanság was a vast marshland but following the drainage works most of the lakes of Hanság and Tóköz disappeared; only the Lake Fehér and the Lake Barbacsi remained. As a result of turf-cutting smaller lakes emerged (Lake Király), all these areas are as strictly protected areas the part of the National Park Fertö-Hanság. A very interesting and successful wetland reconstruction project in the Hanság started in 2001 to restore the open wetlands and the marshes. Its first step was realized in the area Nyirkai-Hany (420 ha) and as a following project in Osli-Hany (1322 ha) in 2013. 


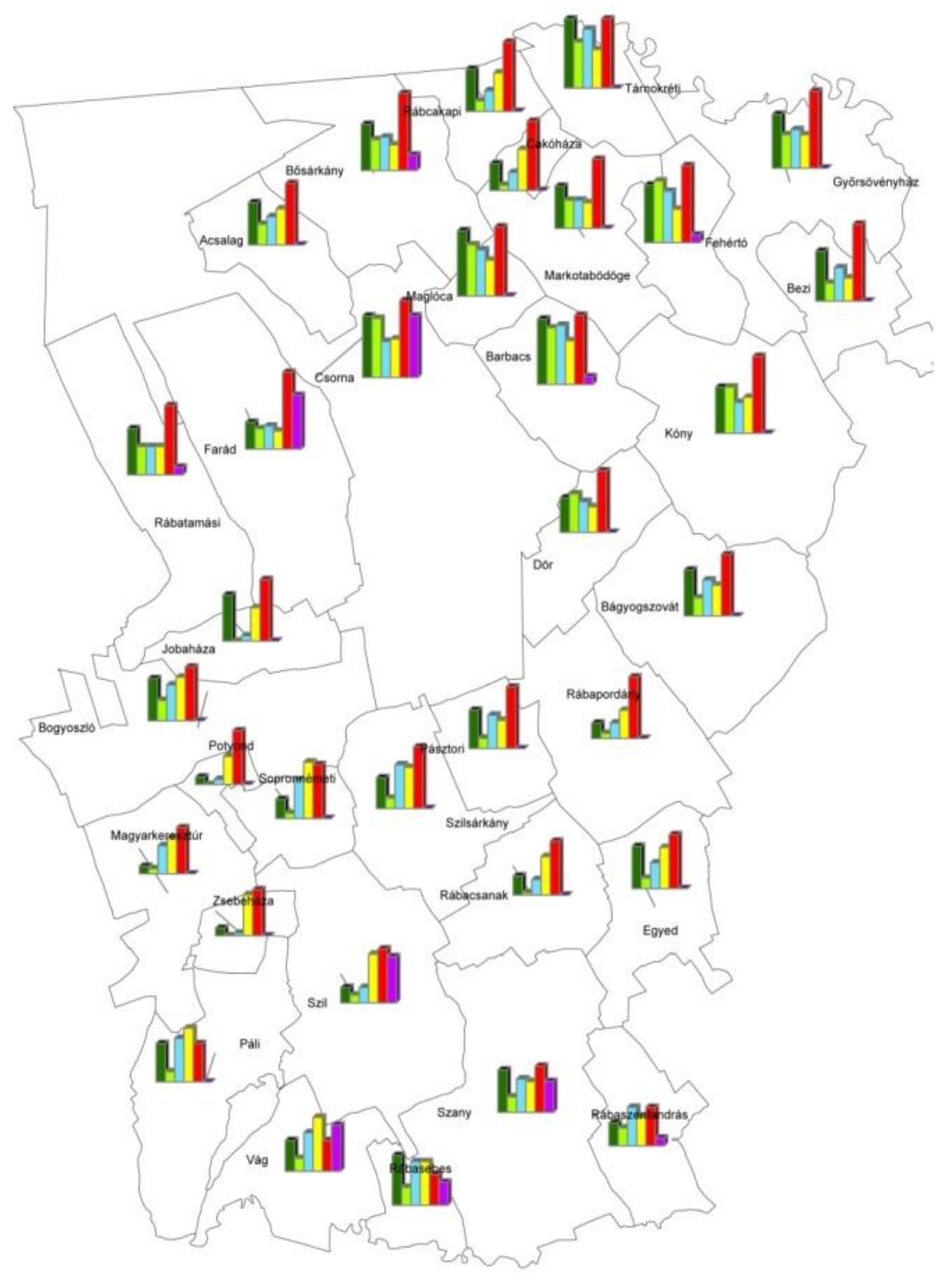




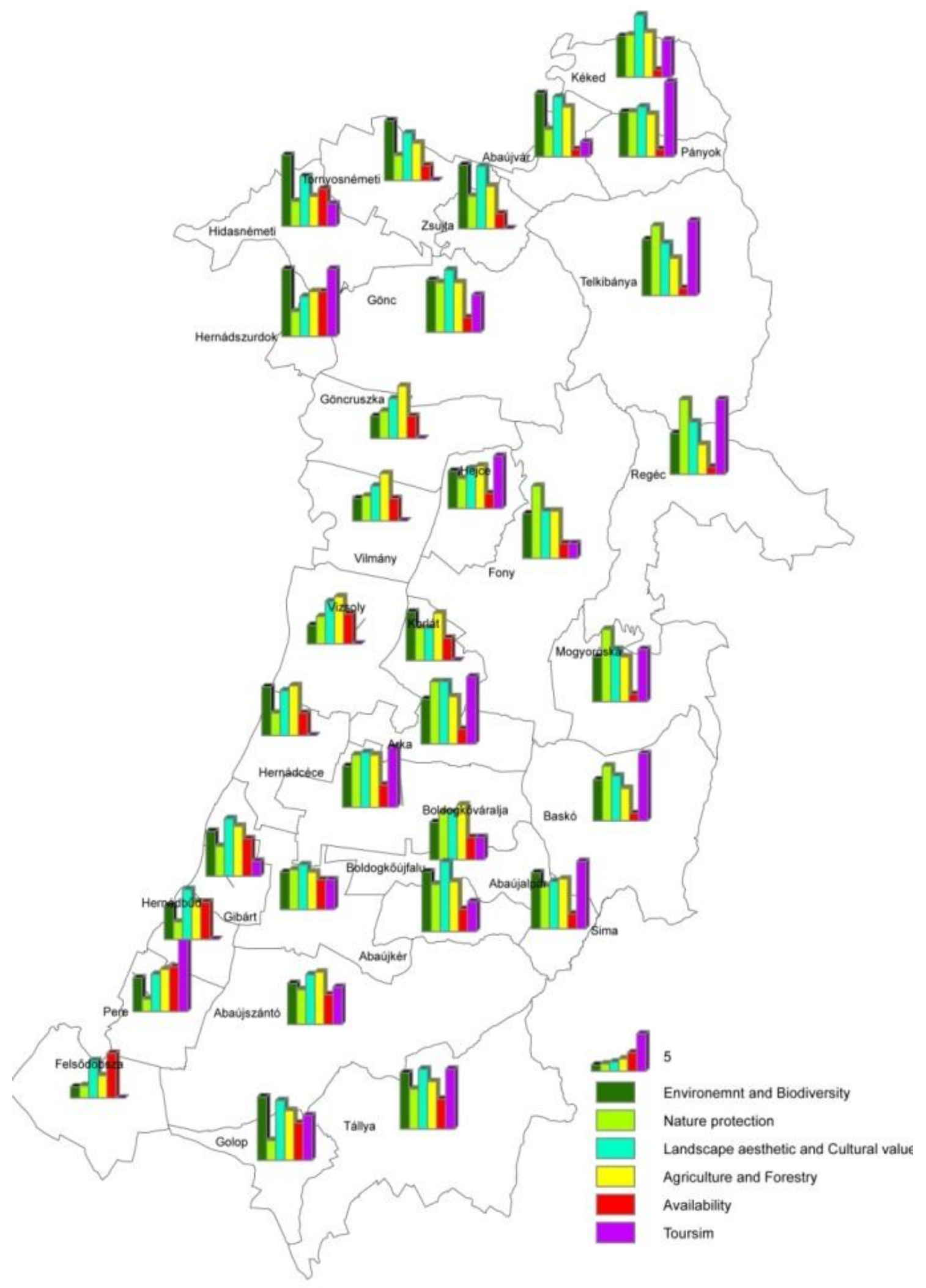

Figure 2. Level of landscape functions on the settlements of micro-region Csorna and Gönc

APPLIED ECOLOGY AND ENVIRONMENTAL RESEARCH 12(4): 867-886.

http://www.aloki.hu • ISSN 15891623 (Print) • ISSN 17850037 (Online)

DOI: $10.15666 /$ aeer/1204 867886

(c) 2014, ALÖKI Kft., Budapest, Hungary 
The flooded Nyirkai-Hany was quickly detected by the breeding and migratory birds. The area became a wetland of international importance (Ramsar site) in 2006 (http://www.ferto-hansag.hu/fhnp-en).

In almost all settlements we can find areas of National Ecologic Network. But meanwhile in settlements of Hanság, Tóköz the National Park and Natura 2000 areas dominate in Rábaköz the areas of National Ecologic Network are in majority. In Rábaköz the areas of National Ecologic Network are mostly meadows. It is important for the farmers because while in the area of Natura 2000 different support schemes are available for farming, in the area of National Ecologic Network there are no such support available which does not help the maintenance of the ecologic values in this intensive agricultural land.

In micro-region of Gönc the Landscape Protection Area of Zemplén has got a big portion of area of some eastern settlements of the micro-region (e.g. Fony, Mogyoróska, Regéc, Arka, Telkibánya). The Landscape Protection Area is one of the most undisturbed and undetected region in Hungary. For several years there have been efforts to declare the area as a national park. The Landscape Protection Area was established in 1984 on 26,496 acres. Certain parts of Nagy-Sertés Mountain, which belongs to Telkibánya, are also forest reserves (F. Nagy, 1996). About 85\% of the Landscape Protection Area's territory is covered by forest, which determines its character.

The share of protected areas of international importance (Natura 2000 areas and Ramsar sites) is high, especially in the western settlements (along the Hernád-river) and the eastern settlements (related to the Landscape Protection Area of Zemplén).

In all of the settlements we can find areas of National Ecological Network. Most of these areas overlap the protected areas of national and/or international importance. The differences can be detected along the small streams, which arise from the Mountains of Zemplén and held toward the Hernád-river. One of our important results is the lack of the Ecological Network in the Valley of Hernád, especially in those settlements, which have big arable fields (e.g. Göncruszka, Vizsoly, Vilmány, Hernádcéce). In the sample area it causes a big problem, because the lack of the ecological corridors between the core areas (in the mountains and along the river) means, that the ecological system can not work as a real network.

\section{Landscape aesthetic and cultural value}

In the micro-region of Csorna the only outstanding cultural value is the baroque Premonstratensian Abbey Church of Csorna but the small villages are rich in folk architecture. So the indicator of cultural heritage shows the highest values in Szilsárkány, Barbacs with old folk houses. The indicator of naturalness show similar values to the indicators of biodiversity and environmental integrity. The values of naturalness are high in settlements of Hanság and Tóköz and mostly low in Rábaköz. As the indicator of diversity represents the length of forest and water borders the values are high in settlements along river Rába (Rábasebes, Vág, Rábaszentandrás) and Rábca and the major canals and lakes of Hanság (Györsövényház, Tárnokréti). Forests are mostly situated in Hanság. Because of the intensive drainage works in Hungary the highest density of canal system can be found in Hanság.

We can distinguish four major landscape character types in the micro-region:

1. The remnants of the former marshland mostly characterized by wetlands, pastures, forests, mosaic landscape. 
2. Drained marshland mostly characterized by low and medium intensity cultivations (Konkoly-Gyúró, 2010).

3. Plain landscape with dominant plough-land

a. Monotonous plain landscape with large plough fields.

b. Plain landscape with mosaic like cultivation.

4. Riverside landscape characterized by high rate of gallery forests with small pastures.

In micro-region of Gönc the most important cultural heritages are located in Gönc (e.g. Bible Museum and Reformed church, Hussite House), in Telkibánya (e.g. Reformed fortified church and wooden headboards cemetery), in Boldogkőváralja (e.g. Castle of Boldogkö), in Vizsoly (e.g. Reformed Church) and in Tállya (e.g. vineyards and wine cellars on the World Heritage Site). Besides these, our results show high value of the cultural heritage in Hejce, Zsujat and Felsödobsza. The reason for this is the richness of folk architecture (e.g. folk houses). The indicator of naturalness shows similar results than the indicator of environmental integrity in micro-region of Gönc. The settlements, located in the Mountains of Zemplén reached high values (e.g. Baskó, Regéc, Mogyoróska,Telkibánya), while the settlements with big cultivated areas have got low values (Felsődobsza, Vizsoly, Vilmány, Pere). Since the indicator of diversity is based on the length of the water and forest borders, the value of it is the highest in the settlements along the Hernád river, especially in the north half of the sample area, where plenty of small lakes and backwaters are located (Zsujta, Abaújvár, Hidasnémeti, Hernádszurdok). The values of the indicator are also high in the eastern settlements, where the forests of the Mountains of Zemplén meet the arable areas (orchards, vineyards). The diversity values are low between these two sides of the micro-region.

We can distinguish four major landscape character types in the sample area:

1. Mountains of Zemplén mainly characterized by broadleaf forest

2. Transition areas on the foothills of Zemplén characterized by old orchards, vineyards and meadows

3. Valley of the Hernád river characterized by big arable areas with narrow stream valleys and along them small groups of trees and bushes

4. Riverside landscape with the Hernád river and along that with gallery forests, backwaters and small lakes

\section{Agriculture and Forestry}

In the micro-region of Csorna the significance of agriculture in the economy, employment and land use is above the national average. The Rábaköz is characterized by intensive agriculture. The ratio of plough fields are extremely high in the microregion (national average $48 \%$, local $66 \%$ with great local differences), in spite of the traditional predominance of grazing the ratio of the grass fields in the region is average today. Hanság, Tóköz is characterized by low, medium intensity of agriculture.

Fruit production is not characteristic either, but there are a few large plantations for example in Sopronnémeti (fruit plantation), Tárnokréti (fruit, vegetable from ecologic production), Szilsárkány. The proportion of area of fruit and vegetable gardens is much less than the national average in spite of the considerable growth during the socialism and during the 1990's when the vegetable growing especially the cucumber which was called the "gold of Rábaköz" was significant. 
Forestry is not important in the region. Most of the forests are situated in the marshland of Hanság (high values of indicator in Csorna) or along the river Rába (Vág, Páli).

Based on the indicator of agricultural potential we can also divide Gönc micro region into two significantly different parts. In the Valley of Hernád the ratio of arable land is very high. These settlements are characterized by big, intensive agricultural fields (Göncruszka, Vilmány, Vizsoly, Felsődobsza, Hernádcéce, Tornyosnémeti). This region historically was called as the "pantry of Kosice", so the agriculture has a great tradition. While the settlements in the Mountains of Zemplén have very small agricultural areas due to the huge forests (Regéc, Fony, Telkibánya, Mogyoróska).

Two main hotspots of vine and fruit potential indicators were detected in Gönc micro-region. First, the southern settlements of the micro-region belong to the "Tokaj Wine Region Historic Cultural Landscape" World Heritage Site, that is why Tállya, Abaújszántó and Golop have a really high value of this indicator. Especially in Tállya and Abaújszántó have big historical vineyards and plenty of wine cellars.

The other interesting area is Gönc and the settlements in its surroundings, which are traditionally fruit product areas ("pálinka of Gönc"). Nowadays plenty of old abandoned orchards are located next to the forests of Zemplén. Despite of this, the fruit production is still a significant sector of the region. Plenty of new, modern orchards were deployed in Gönc, Göncruszka, Hejce, Boldogkőváralja and Boldogkőújfalu.

In Gönc micro-region the result of forestry indicator is more or less the inverse of the indicator of arable land potential results. The settlements situated in the Mountain of Zemplén reached high value of forestry potential. In their economy the forestry has an important role, especially in the case of Fony, Regéc, Mogyoróska, Baskó, Telkibánya, Pányok and Kéked.

\section{Tourism}

Analyzing the accommodation capacity and number of guest nights the results are disappointing in the micro-region of Csorna: the indicator show high tourism potential just in a few settlements: in Hanság and Tóköz just in Csorna, Farád, Bősárkány, and in Rábaköz with the exception of the settlements along the river Rába (Vág, Szany, Szil, Rábasebes) we can not talk about tourism at all. If we look at the recreational activities related to natural endowments we can see almost just ceasing possibilities: the thermal bath of Csorna in spite of the great development plans of the self-government is not functioning (because of ownership conflicts), the former beaches of Rába are abandoned, the lookout tower in Fehértó (Hanság) is run down.

Analyzing the tourism in the surrounding of Gönc our results show duality among the settlements. There are some villages, in which we can not talk about real tourism, in these settlements officially there are no guest accommodation and guest nights. These villages located mainly in the Valley of Hernád (e.g. Zsujta, Göncruszka, Korlát, Vilmány, Hernádbüd).

On the other end of our results is Telkibánya, which reached the significantly highest value of this indicator. We can detect other settlements in the Mountains of Zemplén which have also quite high values (Regéc, Pányok, Sima, Arka, Baskó, Tállya, Hejce). It is interesting, that the two towns of the micro-region have only on intermediate position of our results. Based on this, one can argue, that the main tourism types in the sample area is the rural and the nature-based tourism. We found some settlements with relatively high values along the Hernád river. In this area the water tourism is the main 
tourism type. In the villages some guest accommodations and tourism services help to stimulate the tourism (Pere, Hernádszurdok).

\section{Availability}

The level of availability has great differences in micro-region of Csorna. The settlements along the main traffic corridors and in the vicinity easily accessible even by public transportation as well. The values of availability are insufficient in Southern Rábaköz.

In the micro-region of Gönc similar differences were detected as in micro-region of Csorna. The settlements on the southern and western parts are relatively easily accessible thanks to the main roads of the region. The same villages have got better connections by public transportation as the settlements in the Mountains of Zemplén. The availability of this part of the sample is very low (e.g. Kéked, Pányok, Mogyoróska). Some of the villages are "dead-end" -villages.

\section{Economic situation of the pilot regions}

Figure 3 highlights the unfavorable economic situation of most of the settlements of micro-region of Gönc and the Southern settlements of Rábaköz. In micro-region Csorna the city of Csorna, Bősárkány, Győrsövényház, Kóny, Bősárkány, Szilsákány have the highest values of the economic indicator. From the point of economic development the northern part of micro-region can be also divided in two parts. Settlements of Tóköz neighbouring Csorna have unfavourable values. In the eastern part of Tóköz in the vicinity of the county seat the settlements are popular and developing. In micro-region Gönc the settlements in the Mountains of Zemplén have got relatively high values of the indicator. The economy of these villages is mainly based on the tourism, wine production and forestry. In general, the smaller villages in the Valley of Hernád have got the biggest economic and -related to this - social problems.
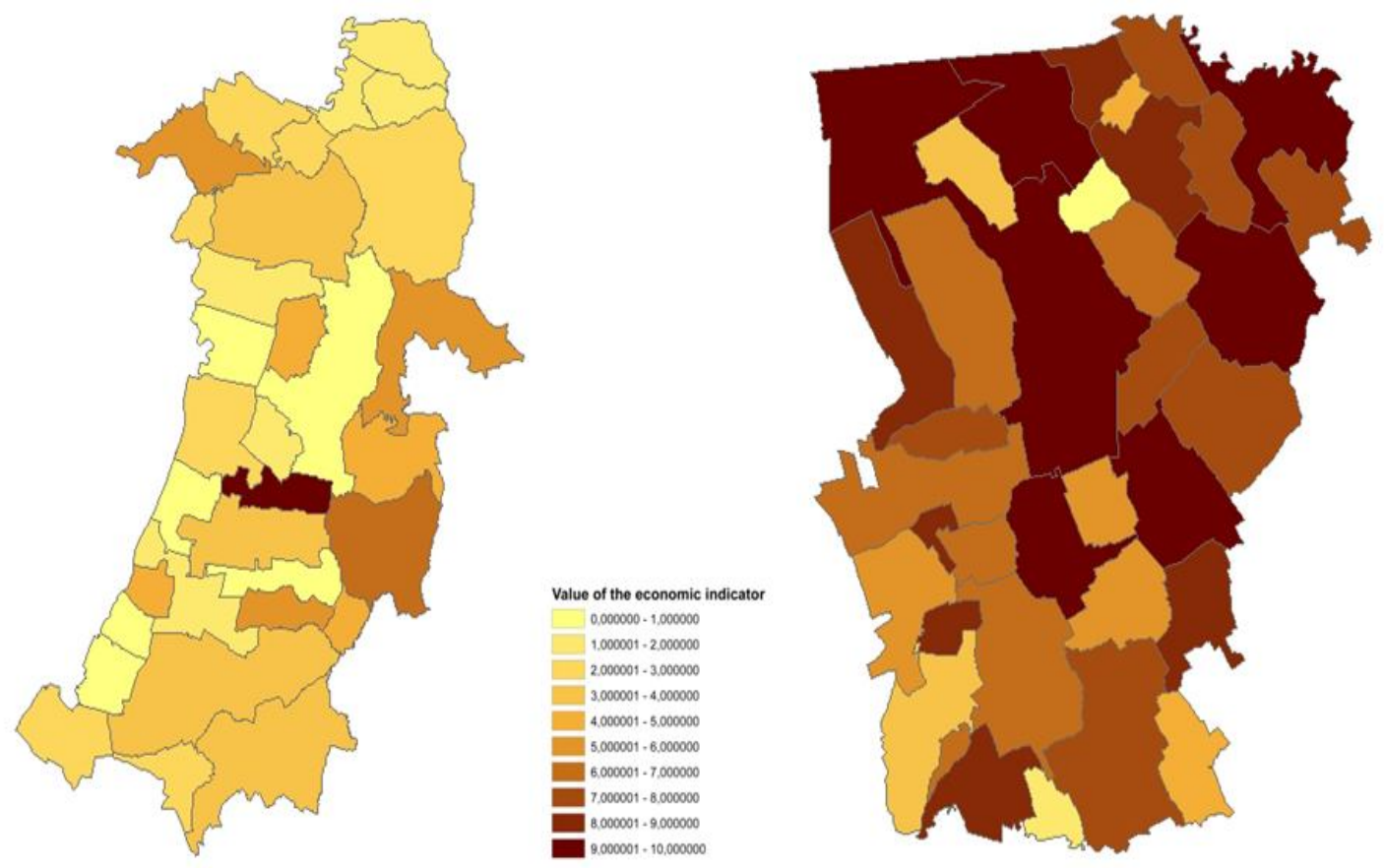

Figure 3. Economic indicator in the settlements of micro-region Csorna and Gönc

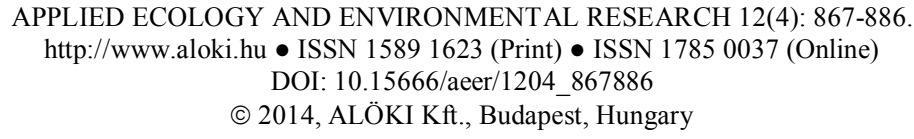




\section{Differences in level of landscape functions, relevant landscape functions between the pilot regions (general indices)}

In order to highlight the main differences and similarities between the pilot-regions we calculated the averages of the settlement values. The diagram shows characteristic differences in the level of landscape functions (Figure 4). The value of most landscape indicators of micro-region Gönc exceeds those of Csorna. The average value of environmental integrity, naturalness, nature protection, diversity in Gönc is mostly double or triple of Csorna. Considering the indicators which influence and represents the economic situation of the regions Csorna has the highest values. Remarkable differences exist in the level of availability and economic situation. Values of tourism and agriculture are higher in Gönc regions, unfortunately these sectors have a lower influence on economic development and employment. In the field of agricultural production in Gönc vine and fruit production have the highest values, arable land potential is higher in Csorna.

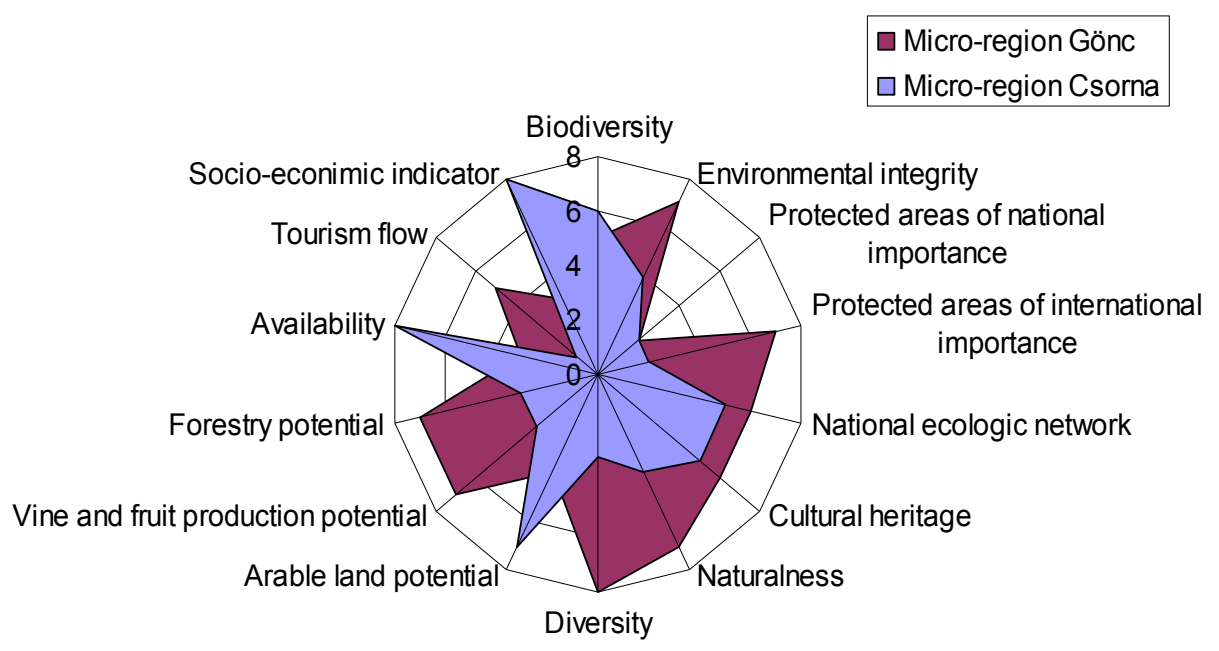

Figure 4. Comparison of values of landscape indicators and level of landscape functions and economic situation between pilot regions

\section{Discussion}

We have found interesting relations between landscape functions, availability and economic situation, but because of distinct interactions between the functions in different situations the correlations vary. Rábaköz is a plain landscape cultivated since centuries where the most common way to increase the amount of agricultural products was obtaining land by meadow-plough land transition. This processes resulted in low rate of extensive areas which causes the low values of environment and biodiversity. Regulation, supporting landscape functions and the aesthetic, cultural value of the landscape are insufficient in Rábaköz.

The other major landscape unit which differs characteristically in micro-region of Csorna is Hanság and Tóköz, which still bears the values of the former vast marshland and the majority of that is under nature protection. Looking at the landscape aesthetics the protected areas are of high value but in the cultivated areas especially plough fields the landscape is monotonous. Significant part of protected areas are strictly protected, there is only one study trail in the region and only two exhibitions of smaller scale.

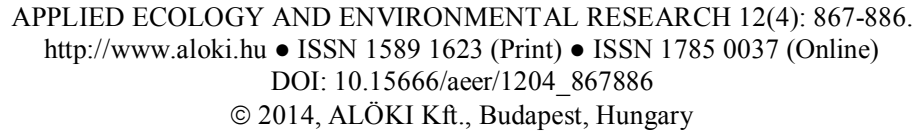


There are no guest houses, apartments of appropriate quality, so tourism; eco-tourism is marginal in Hanság.

In the micro-region of Csorna there is a very strong relation between availability and development potential. Those settlements have good economic conditions which are easily accessible. The settlements in South-Rábaköz where the values of availability are low suffer severe depopulation. Because of the poor conditions of availability the most important economic sector is agriculture whose income-generating capacity and role in employment is insufficient because of the low rate of high value-added agricultural sectors. Agriculture, however, as in the case of most of the settlements of low commuting and other economic activities does not provide competitive salaries to the public. The low rates of intensive horticulture furthermore the low level of processing of agricultural products and a limited scale of complementary activities and income reduces the profitability of agriculture. The monocultural agricultural production causes the insufficient level of several landscape functions. This and the low level of availability have a strong correlation with the poor economic situation, and depopulation trend of Southern-Rábaköz. Landscape management should focus in Rábaköz on diversification of agricultural production and development of the ecologic value of the landscape.

We can also observe correlation between landscape functions, availability and economic situation in Hanság and Tóköz which are rich in natural values. In spite of the high rate of areas of high natural value, the landscape values do not appear as attractions; there are limited opportunities for ecotourism because of the lack of study trails, exhibitions, and lookout towers. All of this reduces the additional income from tourism for local people. In spite of the lack of jobs due to the good availability of the county center the settlements of Eastern-Tóköz remained attractive for the society. Settlements of unfavorable availability in Tóköz in the vicinity of Csorna (WesternTóköz) became deprived communities in spite of the richness of natural values.

Micro-region of Gönc can be divided into different parts according to the landscape function analysis. As a result of our research we identified different landscape function combinations and mechanism. This region was the pantry of Kassa (today the second biggest city of Slovakia) before 1920. Agriculture dominated in the fertile areas, typically in valley of Hernád. The cultivation structure which evolved in times of socialism and maintained up till now caused the marginalization of environmental and natural values. Consequently we measured relative low values in valley of Hernád in case of the groups of environmental and natural indices. Parallel with the marginalization of supporting and regulation functions the provision function is dominant as a consequence of high rate of agricultural use. Similarly to micro-region of Csorna the values of availability are low and this is in strong correlation with the economic development. Mountain of Zemplén characteristically differs from landscape unit of valley of Hernád where we explored different correlations. The cultural and amenity, supporting, and regulation functions are much stronger in these settlements. Forestry, and nature protection are dominant and as a consequence tourism. However, it is interesting that this area has the worst values of accessibility. In this case (in contrast to the micro-region of Csorna) this strengthens the position of tourism and thus of the economy (tourists arriving here are mainly attracted by the relatively untouched nature).

In the transition zone we find a mosaic like system of landscape functions characteristic for Zemplén or Valley of Hernád. The economic situation is not homogeneous either. Those settlements where tourism has a significant role or 
agricultural sectors with relatively high additional value (fruit and vine production) are dominant have better economic indicators.

We can clearly state on the basis of the foregoing that diversified landscape management is needed in both pilot regions. In the Valley of Hernád and Rábaköz the restructuring of agriculture is proposed, where the agricultural sectors of higher additional value shall be more significant (e.g. horticulture, organic farming). The improvement of ecologic value is also important so the planting of elements of mosaic like and the traditional landscape such as vegetation along canals, forest belts, trees and greater areas of pastures should be enhanced. Parallel to it the improvement of availability and cross-border co-operation is needed. In the Mountains Zemplén the main directions of landscape management shall follow the preservation of natural values, nature protection and tourist development (rural, eco and active tourism). The situation of settlements of Hanság and Western-Tóköz are the same but there tourism shall be developed 'from scratch'.

Based on the regional comparison we can clearly state that the economic situation has a strong correlation with availability. It is also obvious that in many cases high environmental-natural potential does not result in economic development. In our opinion this is due to poorly targeted regional and rural development policies. For the better use of landscape potential we call for more professional foundation of these policy documents by detailed landscape management guidelines based on landscape function analysis.

Relation between intensive agriculture and economic situation of the settlements is controversial. The labor intensive agriculture, the higher value-added sectors such as vine production, horticulture or organic farming result in higher rate of employment and better economic situation. The intensive cereal production is not appropriate anymore to provide economic base for the people of villages because of its low labor needs. Furthermore intensive cereal production leads to a decrease of the ecologic and aesthetic values.

Naturally there is a strong correlation between natural and cultural values and tourism in general, however the settlements of Tóköz can not benefit from their natural values due to the strict nature protection regulations and the lack of tourism infrastructure.

To analyze the landscape functions in the pilot-regions we used complex indicators. Unfortunately in many cases there are no appropriate indicators to highlight the multiple functions of the landscape. Indicators often describe and characterize just a narrow fraction of certain landscape functions. For example indicator of monuments (cultural value) describes just the number of cultural values and do not give information about the significance of the monument (local, regional, national, international significance).

Furthermore we aggregated the spatial data for settlements level which also may cause loss of data. For more detailed analysis or possibilities for correction it is also possible to involve wider range of indicators for describing environmental, aesthetic, economic functions of the landscape (agriculture in employment, wooden production etc.).

In conclusion, rural regions possess of different system of landscape functions (looking at structure and functioning). At the beginning of detailed analysis the identification of appropriate indicators is needed, which helps to explore the characters of landscape functions. Next to the identification of landscape functions it is also essential to explore their spatial pattern, combinations and the relations between them. 
In our study we have shown example for an indicator-system adaptable in Hungary. Our studies we demonstrated that it is reasonable to carry out landscape function analysis because of the complexity of system of landscape functions in all rural regions.

\section{REFERENCES}

[1] Ángyán, J., Menyhért, Z. (szerk.) (2004): Alkalmazkodó növénytermesztés, környezet- és tájgazdálkodás. Szaktudás Kiadó Ház, Budapest

[2] Bastian, O. (1997): Gedanken zur Bewertung von Landschaftsfunktionen - unter besonderer Berücksichtigung der Habitatfunktion, Schnevedingen, Germany: Alfred Toepfer Akademie für Naturschutz.

[3] Bastian, O., Krönert, R., Lipský, Z. (2006): Landscape Diagnosis on Different Space and Time Scales - A Challenge for Landscape Planning, Landscape Ecology April 2006, Volume 21, Issue 3: 359-374

[4] Belényesi, M. (2008): A táj és tájgazdálkodás. In: Tamás, J. (szerk.): Agrárium és környezetgazdálkodás. Mezőgazda Kiadó, Budapest

[5] Brandt, J., Vejre, H. (2004): 'Multifunctional Landscapes - Motives, Concepts and Perspectives,". In Brandt, Vejre, H. (eds.): Multifunctional Landscapes - Volume I: Theory, Values and History. Southampton, UK: WIT Press, 3-32.

[6] Clay, G.R., Smidt, R.K. (2004): Assessing the validity and reliability of descriptor variables used in scenic highway analysis. Landscape and Urban Planning Volume 66 Issue 4: 239-255.

[7] Costanza, R., Arge d', R., Groot de, R., Farber, S., Grasso, M., Hannon, B., Limburg, K., Naeem, S., O’Neill, R.V., Paruelo, J., Raskin, R.G., Sutton, P., Belt van den, M. (1997): "The Value of the World's Ecosystem Services and Natural Capital,'. Nature, 387: 253260.

[8] Council of Europe (2000): European Landscape Convention. Chapter 1, Article 1, e

[9] Csemez, A. (1996): Tájtervezés - tájrendezés, Mezőgazda Kiadó, Budapest

[10] Daniel, T.C. (2001): Whiter scenic beauty? Visual landscape quality assessment in the 21st century. Landscape and Urban Planning, Volume 54: 267-282.

[11] de Groot, R. (2006): Function-analysis and valuation as a tool to assess land use conflicts in planning for sustainable, multi-functional landscapes. Landscape and Urban Planning 75:175-186.

[12] De Groot, R., Hein, L. (2007): "Concept and Valuation of Landscape Functions at Different Scales". In Mander, Ü., Wiggering, H. and Helming, K. (eds): Multifunctional Land Use. Berlin Heidelberg New York: Springer, pp. 15-36.

[13] de Groot, R.S. (1992): Functions of Nature: Evaluation of Nature in Environmental Planning, Management and Decision Making. Wolters-Noordhoff, Groningen, pp. 315.

[14] de Groot, R.S., Wilson, M., Boumans, R. (2002): A typology for the description, classification and valuation of Ecosystem Functions. Goods Services Econ. Volume 41 Issue 3 pp. 393-408.

[15] EEA (European Environment Agency) (1998): Europe's environment: the second assessment. European Environment Agency EEA, Copenhagen

[16] EEC (1992): 2078/92 on agricultural production methods compatible with the requirements of the protection of the enviromnent and the maintenance of the countrysid

[17] Ehrlich, P.R.,Ehrlich, A. H. (1981): Interaction Among Landscape Elements: A Core of Landscape Ecology. New York: Random House.

[18] Filepné Kovács K. (2013): Vidéki térségek versenyképességének tájhasználati szempontjai, Doktori értekezés, Budapesti Corvinus Egyetem

[19] Gobster, P.H. (1999): An ecological aesthetic for forest landscape management. Landscape Journal 18 (1): 54-64.

[20] http://www.ferto-hansag.hu/fhnp-en (Retiereved: 05.05.2014.)

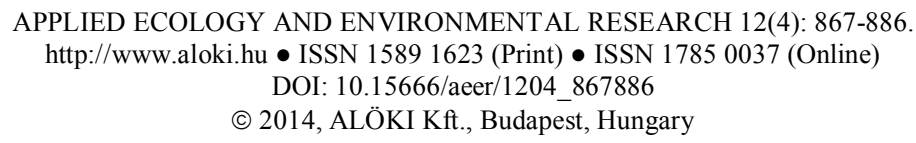


[21] Kaplan, R., Kaplan, S., Brown, T. (1989): Environmental preferences. A comparison of four domains of predictors. Environment and Behavior, Volume 21 Issue 5: 509-530

[22] Kollányi, L. (2004): Táji indikátorok alkalmazási lehetőségei a környezetállapot értékeléséhez. Környezetállapot értékelési program: A környezetállapot értékelésének módszertani és fejlesztési lehetőségei, hatótényezőinek vizsgálata. BKAE Tájtervezési és Területfejlesztési Tanszék, Budapest

[23] Kollányi, L. (2009): Tájértékek kataszterezésének metodikája. Ormos Imre Tudományos Ülésszak, LOV 2009, Tájépítészeti tanulmányok ISBN 2061-5051, pp 159-165.

[24] Konkoly-Gyúró, É. (2010): Határon átívelő tájak karaktere, A Fertő-Haság medence és Sopron térsége. Nyugat-Magyarországi Egyetem Kiadó, Lővérprint, ISBN:978-963-988353-6

[25] Koschke, L., Fürst, C., Frank, S., Makeschin, F.(2012): A multi-criteriaapproach for an integrated land-cover-based assessment of ecosystem services provision to support landscape planning. Ecological Indicators Volume 21 pp. 54-66

[26] Lamarque, P., Quitier, F., Lavorel, S. (2011): The diversity of the ecosystem services concept and its implications for their assessment and management. Compes rendus Biologies, Volume 334, Issues 5-6 pp. 441-449

[27] MEA (Millennium Ecosystem Assessment) (2005): Ecosystems and human well-being: Biodiversity synthesis. World Resource Institue, Washington D.C., 86 p.

[28] OECD (1997): Environmental indicators for agriculture. Vol. 1.: concepts and frameworks. Publications Service, OECD, Paris

[29] OECD (2001): Encironmental indicators for agriculture. Methods and results, executive summary. OECD, Paris

[30] OECD (2007): OECD Regions at a Glance: 2007 Edition. OECD Publishing, Paris, pp. 252

[31] Swanwick, C. (2002): Landscape caharacter assessment. Guidance for England and Scotland. Scottish Natural Heritage and Coutryside Agency, Cheltenham and Edinburgh

[32] TEIR-National Regional Development and Spatial Planning Information System, https://teir.vati.hu/

[33] USDA (United States Department of Agriculture) - Forest Services (1995): Landscape aesthetics: a handbook for scenery management. Agriculture handbook pp. 701.

[34] Willemen, L., Hein, L., van Mensvoort, M.E.F., Verburg, P.H. (2010): Space for people, plants, and livestock? Quantifying interactions among multiple landscape functions in a Dutch rural region. Ecological Indicators Volume 10 pp. 62-73. 